\title{
Actinomycin Antineoplastic Antibiotic
}

National Cancer Institute

\section{Source}

National Cancer Institute. Actinomycin Antineoplastic Antibiotic. NCI Thesaurus. Code C204.

A chromopeptide antineoplastic antibiotic isolated from the bacterial genus

Streptomyces. Actinomycin antibiotics inhibit DNA replication and RNA and protein synthesis by various mechanisms such as intercalating into the minor groove of DNA and interfering with the function of topoisomerase II. 